\title{
Plasma zinc levels, anthropometric and socio-demographic characteristics of school children in eastern Nepal
}

\author{
Ashwini Kumar Nepal ${ }^{1 *}$, Basanta Gelal $^{1}$, Kisundeo Mehta', Madhab Lamsall, ${ }^{1}$ Paras Kumar Pokharel ${ }^{2}$ \\ and Nirmal Baral ${ }^{1}$
}

\begin{abstract}
Background: Zinc deficiency is a major public health problem in many developing countries including Nepal. The present study was designed to assess the prevalence of zinc deficiency and to study the association of zinc deficiency with anthropometric and socio-demographic variables, in school children of eastern Nepal.

Methods: This cross-sectional study included total 125 school children of age group 6-12 years from Sunsari and Dhankuta districts of eastern Nepal. Plasma zinc level was estimated by Flame Atomic Absorption Spectroscopy.

Results: The Median interquartile range (IQR) values of zinc in the two districts Sunsari and Dhankuta were 5.9 $(4.4,7.9) \mu \mathrm{mol} / \mathrm{L}$ and $5.8(4.3,8.4) \mu \mathrm{mol} / \mathrm{L}$ respectively. A total of 55 children $(87.3 \%)$ in Sunsari and $52(83.9 \%)$ in Dhankuta had zinc deficiency, no significant difference was observed in the Median (IQR) plasma zinc levels ( $p=0.9)$ and zinc deficiency patterns $(p=0.3)$ of the two districts. Significant differences were observed in the plasma zinc levels $(p=0.02)$ and zinc deficiency patterns $(p=0.001)$, of the school children having age groups $6-8$ years than in 9-10 and 11-12 years of age, and zinc deficiency patterns between male and female school children $(p=0.04)$ respectively.

Conclusions: The present study showed higher prevalence of zinc deficiency among school children in eastern Nepal. In our study, zinc deficiency was associated with both sex and age. The findings from the present study will help to populate data for policy implementation regarding consumption and supplementation of zinc.
\end{abstract}

Keywords: Plasma zinc levels, Zinc deficiency, Anthropometry, Nepal

\section{Background}

Zinc (Zn) deficiency is a major public health problem in many developing countries including Nepal [1,2]. However, its prevalence is still unknown in most populations [2]. Zn deficiency and its adverse effects are associated with poor growth, immune function depression and increased susceptibility to infections [3]. Manifestation of moderate deficiency of $\mathrm{Zn}$ includes growth retardation and male hypogonadism in adolescents, cell-mediated immune dysfunction, and abnormal neurosensory changes [4]. In Nepal, very few studies have been conducted so far, regarding $\mathrm{Zn}$ deficiency with randomized control trials

\footnotetext{
* Correspondence: nepalashwini@gmail.com

${ }^{1}$ Department of Biochemistry, Faculty of Medicine, B.P. Koirala Institute of Health Sciences, Dharan, Nepal

Full list of author information is available at the end of the article
}

(RCT). In a RCT conducted by Tielsch et al, 2007 in central Nepal, mean(SD) values of $\mathrm{Zn}$ were 11.0 (2.1) $\mu \mathrm{mol} / \mathrm{L}$ in placebo and 11.8 (2.4) $\mu \mathrm{mol} / \mathrm{L}$ in $\mathrm{Zn}$ supplemented children respectively [1]. Supplementation trials of $\mathrm{Zn}$ in pneumonia [5,6], and other diseases affecting mortality [1], anthropometry $[7,8]$ and socio-demographic variables $[9,10]$ have been conducted in Nepalese populations in the past decade. Prevalence and the burden of Zn deficiency in the eastern part of Nepal are yet to be explored. Previous studies being mainly focused on pre-school children or infants, there is a paucity of data on the $\mathrm{Zn}$ status of the school children of Nepal. These school children form the bulk of the growing children population, being more vulnerable to deficiency of $\mathrm{Zn}$ and associated manifestations. Hence, the present study was designed to assess the prevalence of $\mathrm{Zn}$ deficiency, and its association with 
anthropometric and socio-demographic variables, in ethnic Nepalese school children from Sunsari and Dhankuta districts of eastern Nepal.

\section{Methods}

\section{Study sites and subjects}

This cross-sectional study was conducted in a one-year period from August 2009 to August 2010 in school children $(n=125), 6-12$ years of age, from two schools each of the two districts Sunsari (plains) and Dhankuta (hills) from eastern Nepal. School children participating in this study had not received any micronutrient supplements of $\mathrm{Zn}$ or any tablet forms of $\mathrm{Zn}$. The approximate population of Sunsari and Dhankuta at the time of the study were 700,000 and 200,000 respectively.

\section{Anthropometric and socio-demographic evaluation}

Height was measured at nearest $0.1 \mathrm{~cm}$ and weight was adjusted to nearest $0.1 \mathrm{~kg}$. Well-calibrated equipments were used and trained health professionals performed the anthropometric measurements. Stunting (height for age $<\mathrm{z}$ scores -2.0 SD), wasting (weight for age $\mathrm{z}$ scores $<-2.0$ $\mathrm{SD}$ ), thinness (BMI for age $\mathrm{z}$ scores $<-2.0 \mathrm{SD}$ ), underweight (weight for height $\mathrm{z}$ scores $<-2.0 \mathrm{SD}$ ) and overweight (weight for height $\mathrm{z}$ scores $>2.0 \mathrm{SD}$ ) status were defined as per the World Health Organization (WHO), 2007 and Centers for Disease Control and Prevention (CDC), 2000 criteria for growth charts [10]. Age, sex, and the geographical location (hilly or plain) were recorded as the socio-demographic variables.

\section{Laboratory procedures}

Blood samples $(2-3 \mathrm{ml})$ were collected by venipuncture in EDTA coated vacutainer (BD vacutainer, USA) and were transported to the laboratory maintaining cold chain. The blood samples were centrifuged at $3000 \mathrm{~g}$ for 10 mins, and plasma was stored at $-20^{\circ} \mathrm{C}$ until analysis. Plasma was thawed before analysis, and then mixed gently by inverting the tubes. Plasma $\mathrm{Zn}$ level was estimated using Flame Atomic Absorption Spectrometry (Thermo Elemental, UK) [11]. All test tubes for $\mathrm{Zn}$ analysis were thoroughly acid washed ( $0.1 \%$ Nitric acid) and rinsed with double distilled deionized water. Plasma sample was diluted five times in deionized water, i.e. $500 \mu \mathrm{L}$ of plasma was diluted with $2 \mathrm{~mL}$ deionized water. The instrumental gas flow settings were adjusted and the aspiration rate was established to optimize signal and minimize background noise. Zn working calibrators were aspirated sequentially from the most dilute to the most concentrated, aspiration was continued until the readings were stable. The resulting values were used to establish the calibration curves by use of a least squares regression fit. The specimen concentration was calculated from the absorbance readings by interpolation from the calibration curve. Mean \pm SD values for quality control sera for Zn (Seronorm Trace Elements Serum $\mathrm{L}_{1}$ and $\mathrm{L}_{2}$, Norway) were $28.5 \pm 0.8 \mu \mathrm{mol} / \mathrm{L}(\mathrm{CV} 2.9 \%, \mathrm{n}=$ 5) for $\mathrm{L}_{1}$ and $32.4 \pm 2.6 \mu \mathrm{mol} / \mathrm{L}(\mathrm{CV} 8.1 \%, \mathrm{n}=5)$ for $\mathrm{L}_{2}$. The corresponding certified values were 26.6 (range 24.1$29.1 \mu \mathrm{mol} / \mathrm{L}$ ) for $\mathrm{L}_{1}$ and 37.3 (range 27.1-47.5 $\mu \mathrm{mol} / \mathrm{L}$ ) for $\mathrm{L}_{2}$ respectively. $\mathrm{Zn}$ deficiency was defined as per the WHO criteria: < $9.9 \mu \mathrm{mol} / \mathrm{L}$ for school-age children of $<$ 10 years of age, $<10.7 \mu \mathrm{mol} / \mathrm{L}$ for male school children of $>10$ years and $<10.15 \mu \mathrm{mol} / \mathrm{L}$ for female school children of $>10$ years of age respectively [12].

\section{Ethical clearance}

School children, teachers and guardians were briefly explained about the purpose of the study, with educational information regarding $\mathrm{Zn}$ deficiency. Ethical approval and written consent was obtained from the parents or guardians of the school children and the school-teachers, to collect the blood samples for the plasma $\mathrm{Zn}$ estimation. The ethical clearance for this study was approved from the Institutional Ethical Review Board of B.P. Koirala Institute of Health Sciences (BPKIHS), Dharan, Nepal.

\section{Statistical analysis}

Data were analyzed with Statistical Package for Social Sciences (SPSS) version 16.0 (SPSS Inc., Chicago, USA). Data were tested for normality using Kolmogorov Smirnov test. Chi Square test was applied to compare the association of qualitative non-parametric data. Man Whitney test and Krushkal Wallis test was applied for the non-parametric numerical data. Binary logistic regression was applied to compare Zn deficiency patterns in male and female school children. Pairwise differences of plasma Zn levels between males Vs females were compared after adjustment for age and vice versa by multiple logistic regression. Anthropometric indices, height for age $\mathrm{Z}$ scores, weight for age $\mathrm{Z}$ scores, BMI for age $\mathrm{Z}$ scores and weight for height $\mathrm{Z}$ scores were calculated using Epi Info version 6.0 (CDC, USA) and also manually compared with the WHO growth reference charts, 2007 and CDC Growth Charts, 2000. P values less than 0.05 were considered as statistically significant at $95 \%$ confidence intervals (CI).

\section{Results}

\section{Socio-demographic and anthropometric variables}

The Mean \pm SD age of school children enrolled for the study $(n=125)$ were $9.2 \pm 1.9$ years with Mean \pm SD height and weight $12.3 \pm 11.2$ centimeters and $23.4 \pm 6.2$ kilograms respectively. Anthropometric and socio-demographic variables including: stunting, wasting, thinness, underweight and overweight status and the distribution of school children in categories of age groups, sex and districts are explained in Table 1. 
Table 1 Plasma zinc levels and zinc deficiency in various categories

\begin{tabular}{|c|c|c|c|c|c|c|c|}
\hline Variables & Categories & $\mathrm{N}(\%)$ & $\begin{array}{l}\text { Median IQR plasma } \\
\text { zinc levels }(\mu \mathrm{mol} / \mathrm{L})\end{array}$ & $P$ value & Zinc deficient $\mathrm{n}(\%)$ & Zinc sufficient $\mathrm{n}(\%)$ & $P$ value \\
\hline \multirow[t]{3}{*}{ Age (years) } & $6-8$ & $50(40.0)$ & $6.7(4.8,10.2)$ & 0.02 & $37(74.0)$ & 13(26.0) & 0.001 \\
\hline & $9-10$ & $42(33.6)$ & $5.6(4.3,7.1)$ & & $37(88.1)$ & $5(11.9)$ & \\
\hline & $11-12$ & $33(26.4)$ & $5.6(4.0,7.2)$ & & $33(100)$ & $0(0)$ & \\
\hline \multirow[t]{2}{*}{ Sex } & Male & $68(54.4)$ & $5.8(4.5,7.7)$ & 0.57 & $62(91.2)$ & $6(8.8)$ & 0.04 \\
\hline & Female & $57(45.6)$ & $5.9(4.3,8.5)$ & & 45(78.9) & $12(21.1)$ & \\
\hline \multirow[t]{2}{*}{ Districts } & Sunsari & $63(50.4)$ & $5.9(4.4,7.9)$ & 0.9 & 55(87.3) & $8(12.7)$ & 0.3 \\
\hline & Dhankuta & $62(49.6)$ & $5.8(4.3,8.4)$ & & $52(83.9)$ & 10(16.1) & \\
\hline \multirow[t]{2}{*}{ Stunting } & Present & $43(34.4)$ & $5.7(4.5,7.4)$ & 0.59 & $39(90.7)$ & $4(9.3)$ & 0.1 \\
\hline & Absent & $82(65.6)$ & $5.9(4.2,8.6)$ & & $68(82.1)$ & 14(17.9) & \\
\hline \multirow[t]{2}{*}{ Thinness } & Present & 19(15.2) & $5.6(3.8,7.5)$ & 0.22 & 17(89.5) & $2(10.5)$ & 0.4 \\
\hline & Absent & 106(84.8) & $5.9(4.4,7.9)$ & & $90(84.9)$ & 16(15.1) & \\
\hline \multirow[t]{2}{*}{ Wasting } & Present & $4(3.2)$ & $5.7(3.7,9.7)$ & 0.78 & $3(75)$ & $1(25)$ & 0.4 \\
\hline & Absent & $121(96.8)$ & $5.9(4.3,7.7)$ & & 104(86) & $17(14)$ & \\
\hline \multirow[t]{2}{*}{ Underweight } & Present & $37(29.6)$ & $5.6(4.5,7.7)$ & 0.781 & $29(78.4 \%)$ & $8(21.6 \%)$ & 0.5 \\
\hline & Absent & 88(70.4\%) & $5.9(4.3,7.7)$ & & 78(88.6\%) & $10(11.4 \%)$ & \\
\hline \multirow[t]{2}{*}{ Overweight } & Present & $4(3.2 \%)$ & $5.0(4.1,6.0)$ & 0.362 & 4(100\%) & - & 0.1 \\
\hline & Absent & $121(96.8 \%)$ & $5.9(4.3,7.8)$ & & $103(85 \%)$ & $18(14.9 \%)$ & \\
\hline
\end{tabular}

Man Whitney $U$ test and Krushkal Wallis test was applied to compare the non-parametric numerical data, Chi Square test was applied to associate the non-parametric qualitative data, the level of significance was at $95 \% \mathrm{Cl}$.

\section{Plasma zinc levels and its association with socio-demographic factors}

Plasma $\mathrm{Zn}$ levels were not normally distributed, as tested by Kolmogorov-Smirnov test $(\mathrm{n}=125$, $\mathrm{p}$ value $<0.001)$. The median interquartile range (IQR) values of plasma Zn levels in Sunsari and Dhankuta were $5.9(4.4,7.9)$ $\mu \mathrm{mol} / \mathrm{L}$ and $5.8(4.3,8.4) \mu \mathrm{mol} / \mathrm{L}$, where as mean $\pm \mathrm{SD}$ values and median IQR of plasma $\mathrm{Zn}$ in overall school children were $6.8 \pm 3.5 \mu \mathrm{mol} / \mathrm{L}$ and $5.8(4.3,7.7)$ respectively. Zn deficient school children were 55(87.3\%) in Sunsari and 52 (83.9\%) in Dhankuta. No significant difference was observed in the median (IQR) plasma $\mathrm{Zn}$ levels $(\mathrm{p}=0.9)$ and $\mathrm{Zn}$ deficiency patterns $(\mathrm{p}=0.3)$ of the two districts. There was significant difference in the plasma $\mathrm{Zn}$ levels of school children having 6-8 years of age, than $8-10$ and $11-12$ years of age $(\mathrm{p}=0.02)$, and $\mathrm{Zn}$ deficiency patterns of the three age groups $(\mathrm{p}=0.001)$ (Table 1). Borderline significant $\mathrm{Zn}$ deficiency patterns were observed among the male and female groups $(\mathrm{p}=0.04)$ but not in their median (IQR) plasma $\mathrm{Zn}$ levels $(\mathrm{p}=0.5)($ Table 1$)$. Male school children were at 2.75 times risk of Zn deficiency than female students; Odds Ratio 2.75 (0.96-7.8) 95\% CI as shown by logistic regression. Multivariate analysis of plasma $\mathrm{Zn}$ levels with male vs female adjusted with age showed negative associations with age $(\beta=-0.4,95 \% \mathrm{CI}-0.7--0.07, \mathrm{p}=0.01)$ (step1) Vs $(\beta=-0.3,95 \% \mathrm{CI}-0.7--0.5, \mathrm{p}=0.02)$ (step 2$)$ and no significant associations with sex $(\beta=-1.6,95 \%$ CI -0.1 $0.7, \mathrm{p}=0.4)($ step 2$)$ respectively (Table 2$)$.

\section{Plasma zinc levels and its association with} anthropometric indices

There were no significant differences in $\mathrm{Zn}$ deficiency patterns and plasma $\mathrm{Zn}$ levels with stunting, wasting, thinness, underweight and overweight status of the school children (Table 1). Zn deficiency was higher in school children having overweight [100\% (4/4) Vs 85\% (103/121) $(\mathrm{p}=0.1)]$ followed by stunting $[90.7 \%(39 / 43)$ Vs $82.1 \%$ $(68 / 82)(\mathrm{p}=0.1)]$, thinness $[89.5 \%(17 / 19)$ Vs $84.9 \%(90 /$ 106) $(\mathrm{p}=0.4)]$, wasting $[75 \%(3 / 4)$ Vs $86 \%(104 / 121)(\mathrm{p}=$ $0.4)]$ and underweight $[78.4 \%(29 / 37)$ Vs $88.6 \%(78 / 88)$ $(\mathrm{p}=0.5)$ ] status, than in $\mathrm{Zn}$ sufficient children respectively (Table 1). Plasma Zn levels were lower in school children having overweight $[5.0(4.1,6.0) \mu \mathrm{mol} / \mathrm{L}$ Vs $5.9(4.3,7.8)$ $\mu \mathrm{mol} / \mathrm{L}(\mathrm{p}=0.3)]$, followed by underweight $[5.6(4.5,7.7)$ $\mu \mathrm{mol} / \mathrm{L}$ Vs $5.9(4.3,7.7) \mu \mathrm{mol} / \mathrm{L}(\mathrm{p}=0.7)]$, thinness $[5.6$ $(3.8,7.5) \mu \mathrm{mol} / \mathrm{L}$ Vs $5.9(4.4,7.9) \mu \mathrm{mol} / \mathrm{L}(\mathrm{p}=0.2)]$, stunting $[5.7(4.5,7.4) \mu \mathrm{mol} / \mathrm{L}$ Vs $5.9(4.2,8.6) \mu \mathrm{mol} / \mathrm{L}(\mathrm{p}=0.5)]$, and wasting status $[5.7(3.7,9.7) \mu \mathrm{mol} / \mathrm{L}$ Vs $5.9(4.3,7.7) \mu \mathrm{mol} / \mathrm{L}$ $(\mathrm{p}=0.7)]$ respectively (Table 1$)$.

\section{Discussion}

Present study showed higher prevalence of Zn deficiency and low plasma $\mathrm{Zn}$ levels in school children having age group of 9-10 and 11-12 years age, than 6-8 years age. Some investigators have shown tendency for serum $\mathrm{Zn}$ to increase with age $[13,14]$, while others showed no change in serum $\mathrm{Zn}$ with increasing age [3,15]. Ma et al, 2008 in China showed that proportions of inadequate 


\begin{tabular}{|c|c|c|c|c|}
\hline Variables & $\begin{array}{l}\text { Regression } \\
\text { coefficient ( } \beta \text { ) }\end{array}$ & $\begin{array}{l}\text { Standard } \\
\text { error }\end{array}$ & $\begin{array}{l}95 \% \text { Confidence } \\
\text { intervals }\end{array}$ & $P$ value \\
\hline \multicolumn{5}{|l|}{ Step 1} \\
\hline Constant & 10.5 & 1.5 & & \\
\hline Age & -0.4 & 0.1 & $-0.7--0.07$ & 0.01 \\
\hline \multicolumn{5}{|l|}{ Step 2} \\
\hline Constant & 10.6 & 1.5 & & \\
\hline Age & -0.3 & 0.1 & $-0.7--0.5$ & 0.02 \\
\hline Sex & -1.6 & 0.6 & $-0.1-0.7$ & 0.4 \\
\hline
\end{tabular}

Pair-wise differences of zinc levels between males vs females after adjustment for age and vice-versa were assessed in a multivariate model.

$\mathrm{Zn}$ intakes, were $15.9 \%$ and $12.9 \%$ in age groups $4-6$ years and 7-10 years of age [14]. Increased requirements of $\mathrm{Zn}$ in the growing school age children may be due to the requirement of pubertal growth spurt, hormonal influences and co-existing micronutrient deficiencies [16]. Relationships of $\mathrm{Zn}$ deficiency, associated with age can be explained on the basis of confounding effects of pubertal status and tanner stage, constraints on growth due to chronic infection and the co-existence of other growth limiting micronutrient deficiencies such as iodine, as described in a previous study [17].

We found higher prevalence of $\mathrm{Zn}$ deficiency and low plasma $\mathrm{Zn}$ levels in male subjects than in female subjects, which reflects the higher $\mathrm{Zn}$ requirements of male than female, which may be due to higher lean body mass and higher growth rate of male than female. This is supported by Hotz and Brown (2004), who showed male had 2 fold greater risk of being $\mathrm{Zn}$ deficient [12]. However, Fesharakinia et al (2009) in East Iran showed the mean $\mathrm{Zn}$ levels in serum were markedly higher in girls than in boys [3]. A similar sex related trend in serum $\mathrm{Zn}$ concentration, as our study has been documented by some [3,18-20] but not all investigators [13,15,21,22].

In our study, highest prevalence of $\mathrm{Zn}$ deficiency was observed in the overweight and the stunted school children, where as lowest plasma $\mathrm{Zn}$ levels were found in the school children having overweight and underweight status. Despite the biochemical evidence of association of $\mathrm{Zn}$ deficiency with anthropometric status, we did not detect any significant relationships between plasma $\mathrm{Zn}$ levels and anthropometric status in our study. Which may be accountable to the relationships associated with the pubertal status of the school children, constraints on growth due to chronic infection and the co-existence of other growth limiting micronutrient deficiencies in addition to $\mathrm{Zn}[12,17]$. The association between serum $\mathrm{Zn}$ level and anthropometric status is not so clear, several investigators have found varying results. Singla et al, (1996) reported significant association of height for age z-scores with $\mathrm{Zn}$ deficiency among 58 children ( 3 months- 5 years of age) in India [23]. Similarly, association of zinc deficiency with stunting was shown by Fesharakinia et al, 2009 in Iran, where $35 \%$ of school children (9-11 years age) who were stunted had zinc deficiency [3]. In a study conducted by Qin et al, 2009 in China among 2400 school children (6-9 years of age) no significant association was found between serum $\mathrm{Zn}$ and height for age $\mathrm{Z}$ scores (stunting), which was supported by our study [20]. Brown et al, 2002 in a meta-analysis study, concluded that children supplemented with $\mathrm{Zn}$ had greater growth increments than control groups and there was no clear pattern of response with change for weight for height $\mathrm{Z}$ scores with $\mathrm{Zn}$ supplementation [24].

Previous studies in other regions have shown variable plasma Zn levels in school children. Hettiarachchi et al, (2006) reported $\mathrm{Zn}$ deficiency in $51.5 \%$ and $58.5 \%$ boys and girls in a study population of 945 school children (12-16 years) in Srilanka [25]. Some of the previous studies of mean \pm SD plasma Zn reported in other parts of the world were: i) Mahmmodi et al, 2001; Iran, age (years) 12-14 $(\mathrm{n}=881) 14.6 \pm 2.7 \mu \mathrm{mol} / \mathrm{L}$ [26], ii) Arvinitidou et al, 2007; Greece, age (years) 3-14 $(\mathrm{n}=105) 15 \mu \mathrm{mol} / \mathrm{L}$ [22], iii) Ohtake et al, 1976; Japan, age (years) 6-12 $(\mathrm{n}=156), \quad 14.1 \pm 1.9 \mu \mathrm{mol} / \mathrm{L}[15]$, iv) Ndeezi et al, 2009; Uganda, age (years) $1-6(\mathrm{n}=247) 10 \pm 2.9 \mu \mathrm{mol} / \mathrm{L}$ [27] and, v) Amare et al, 2012; Ethiopia, age (years) 10-14 ( $\mathrm{n}=100), \quad 13.22 \pm 6.5 \mu \mathrm{mol} / \mathrm{L}$ [28]. Our study showed mean \pm SD plasma $\mathrm{Zn}(6.8 \pm 3.5 \mu \mathrm{mol} / \mathrm{L})$, which was lower as compared to other studies.

\section{Limitations}

The present study has few limitations. Firstly: the key determinants of $\mathrm{Zn}$ status, including: hair zinc levels, iron or hemoglobin status for anemia, presence of acute illness, inflammation markers, including $\mathrm{C}$ Reactive Protein and serum Albumin were not estimated in this study. Secondly, the pubertal status and tanner stage of the school children were not known which limits to draw conclusions about effects of zinc deficiency in anthropometric status, and small sample size of our study limits to investigate the prevalence of $\mathrm{Zn}$ deficiency in these regions.

\section{Conclusion}

Our study showed considerably low plasma $\mathrm{Zn}$ levels in the school children, as compared to other studies. It is recommended that a regular supplementation of $\mathrm{Zn}$ should be provided, to $\mathrm{Zn}$ deficient groups, in order to prevent the adverse consequences of $\mathrm{Zn}$ deficiency. Populations based larger studies should be conducted in these regions to investigate the prevalence of $\mathrm{Zn}$ deficiencies and establish the confounding factors of $\mathrm{Zn}$ 
deficiency, such as dietary source, water sources, environmental and genetic factors.

The present study suggested higher prevalence of $\mathrm{Zn}$ deficiency in school children of eastern Nepal. In our study, $\mathrm{Zn}$ deficiency was associated with both sex and age. The findings from the present study will help to populate data for the implementation of policy regarding consumption and supplementation of $\mathrm{Zn}$, in $\mathrm{Zn}$ deficient school children. Also, our study urges the need of educational programs regarding $\mathrm{Zn}$ deficiency, micronutrient National surveys in school children including $\mathrm{Zn}$, and supplementation of $\mathrm{Zn}$ to the vulnerable groups. The policy-making and concerned governing bodies should work on developing and implementing the policy that $\mathrm{Zn}$ should not only be supplemented in pneumonia, diarrhea and other disease conditions, but also careful examination of anthropometric and nutritional indices should be considered. Supplementation to severely malnourished children is also essential for elimination of $\mathrm{Zn}$ deficiency. Establishment of normative values of $\mathrm{Zn}$ in Nepalese children should also be continued. Further substantial studies should be conducted both by the Government and Non-government organizations to establish the determinants of severe $\mathrm{Zn}$ deficiency in these regions.

\section{Competing interests}

The authors declare that they have no competing interests.

\section{Authors' contributions}

AKN contributed to the study design, acquisition of data, laboratory analysis, analysis and interpretation of data, and drafted the manuscript. BG and KDM contributed to the study design, acquisition of data. ML contributed to study design, interpretation of data, and drafted the manuscript. NB and PKP contributed to the revision of the manuscript. NB contributed to study design. All authors read and approved the final manuscript.

\section{Acknowledgement}

We would like to thank Department of Biochemistry, B.P. Koirala Institute of Health Sciences, for allowing us to conduct this research. Special thanks to Strengthening of Environmental Administration and Management Nepal (SEAM-N) Dharan, Nepal and SEAM-N, Biratnagar, Nepal for providing a training grant and the laboratory facility for Atomic Absorption spectrophotometry.

\section{Author details}

${ }^{1}$ Department of Biochemistry, Faculty of Medicine, B.P. Koirala Institute of Health Sciences, Dharan, Nepal. ${ }^{2}$ Department of Community Medicine, Faculty of Medicine, B.P. Koirala Institute of Health Sciences, Dharan, Nepal.

Received: 16 July 2013 Accepted: 7 January 2014

Published: 9 January 2014

\section{References}

1. Tielsch JM, Khatry SK, Stoltzfus RJ, Katz J, LeClerq SC, Adhikari R, et al: Effect of daily zinc supplementation on child mortality in southern Nepal: a community-based, cluster randomised, placebo-controlled trial. Lancet 2007, 370:1230-1239.

2. Chandyo RK, Strand TA, Mathisen M, Ulak M, Adhikari RK, Bolann BJ, et al: Zinc deficiency is common among healthy women of reproductive age in Bhaktapur, Nepal. J Nutr 2009, 139:594-597.

3. Fesharakinia AZA, Sharifzadeh GR: Prevalence of zinc deficiency in elementary school children of South Khorasan Province (East Iran). Iran J Pediatr 2009, 19:249-254.

4. Prasad AS: Zinc: mechanisms of host defense. J Nutr 2007, 137:1345-1349.
5. Basnet S, Shrestha PS, Sharma A, Mathisen M, Prasai R, Bhandari N, et al: A randomized controlled trial of zinc as adjuvant therapy for severe pneumonia in young children. Pediatrics 2012, 129:701-708.

6. Valentiner-Branth P, Shrestha PS, Chandyo RK, Mathisen M, Basnet S, Bhandari $N$, et al: A randomized controlled trial of the effect of zinc as adjuvant therapy in children 2-35 mo of age with severe or nonsevere pneumonia in Bhaktapur, Nepal. Am J Clin Nutr 2010, 91:1667-1674.

7. Surkan PJ, Shankar M, Katz J, Siegel EH, Leclerq SC, Khatry SK, et al: Beneficial effects of zinc supplementation on head circumference of Nepalese infants and toddlers: a randomized controlled trial. Eur J Clin Nutr 2012, 66:836-842.

8. Stewart CP, Christian P, LeClerq SC, West KP Jr, Khatry SK: Antenatal supplementation with folic acid + iron + zinc improves linear growth and reduces peripheral adiposity in school-age children in rural Nepal. Am J Clin Nutr 2009, 90:132-140.

9. Christian P, Jiang T, Khatry SK, LeClerq SC, Shrestha SR, West KP Jr: Antenatal supplementation with micronutrients and biochemical indicators of status and subclinical infection in rural Nepal. Am J Clin Nutr 2006, 83:788-794.

10. Murray-Kolb LE, Khatry SK, Katz J, Schaefer BA, Cole PM, LeClerq SC, et al: Preschool micronutrient supplementation effects on intellectual and motor function in school-aged Nepalese children. Arch Pediatr Adolesc Med 2012, 166:404-410.

11. Smith JC Jr, Butrimovitz GP, Purdy WC: Direct measurement of zinc in plasma by atomic absorption spectroscopy. Clin Chem 1979, 25:1487-1491

12. Brown KH, Rivera JA, Bhutta Z, Gibson RS, King JC, Lonnerdal B, et al: International Zinc Nutrition Consultative Group (IZiNCG) technical document \#1. Assessment of the risk of zinc deficiency in populations and options for its control. Food Nutr Bull 2004, 25:S99-203.

13. Alarcon OM, Reinosa Fuller J, Silva TM, Angarita C, Teran E, Navas M, et al: Serum level of $\mathrm{Zn}, \mathrm{Cu}$ and $\mathrm{Fe}$ in healthy schoolchildren residing in Merida, Venezuela. Arch Latinoam Nutr 1997, 47:118-122.

14. Ma G, Jin Y, Li Y, Zhai F, Kok FJ, Jacobsen E, Yang X: Iron and zinc deficiencies in China: what is feasible and cost-effective strategy? Public Health Nutr 2008, 11:632-638.

15. Ohtake M, Tamura T: Serum zinc and copper levels in healthy Japanese children. Tohoku J Exp Med 1976, 120:99-103.

16. Thurlow RA, Winichagoon P, Pongcharoen T, Gowachirapant S, Boonpraderm A, Manger MS, et al: Risk of zinc, iodine and other micronutrient deficiencies among school children in North East Thailand. Eur J Clin Nutr 2006, 60:623-632.

17. Filteau SM, Tomkins AM: Micronutrients and tropical infections. Trans $R$ Soc Trop Med Hyg 1994, 88:1-3. 26.

18. Smit Vanderkooy PD, Gibson RS: Food consumption patterns of Canadian preschool children in relation to zinc and growth status. Am J Clin Nutr 1985, 45:609-616.

19. Cavan KR, Gibson RS, Grazioso CF, Isalgue AM, Ruz M, Solomons NW: Growth and body composition of periurban Guatemalan children in relation to zinc status: a cross-sectional study. Am J Clin Nutr 1993, 57:334-343.

20. Qin Y, Melse-Boonstra A, Zhao J, Wu M, Hu X, Kok FJ: Stunting and zinc deficiency among primary school children in rural areas with low soil zinc concentrations in Jiangsu Province, China. Asia Pac J Clin Nutr 2009, 18(1):15-21.

21. Udomkesmalee E, Dhanamitta S, Yhoung-Aree J, Rojroongwasinkul N, Smith JC Jr: Biochemical evidence suggestive of suboptimal zinc and vitamin A status in schoolchildren in northeast Thailand. Am J Clin Nutr 1990, 52:564-567.

22. Arvanitidou V, Voskaki I, Tripsianis G, Athanasopoulou H, Tsalkidis A, Filippidis $S$, et al: Serum copper and zinc concentrations in healthy children aged 3-14 years in Greece. Biol Trace Elem Res 2007, 115:1-12.

23. Singla PN, Chand P, Kumar A, Kachhawaha JS: Serum, zinc and copper levels in children with protein energy malnutrition. Indian J Pediatr 1996, 63:199-203.

24. Brown KH, Peerson JM, Rivera J, Allen LH: Effect of supplemental zinc on the growth and serum zinc concentrations of prepubertal children: a meta-analysis of randomized controlled trials. Am J Clin Nutr 2002, 75:1062-1071.

25. Hettiarachchi M, Liyanage C, Wickremasinghe R, Hilmers DC, Abrahams SA: Prevalence and severity of micronutrient deficiency: a cross-sectional study among adolescents in Sri Lanka. Asia Pac J Clin Nutr 2006, 15:56-63. 
26. Mahmoodi MR, Kimiagar SM: Prevalence of zinc deficiency in junior high school students of Tehran City. Biol Trace Elem Res 2001, 81:93-103.

27. Ndeezi G, Tumwine JK, Bolann BJ, Ndugwa CM, Tylleskar T: Zinc status in HIV infected Ugandan children aged 1-5 years: a cross sectional baseline survey. BMC Pediatr 2010, 10:68.

28. Amare B, Moges B, Fantahun B, Tafess K, Woldeyohannes D, Yismaw G, et al: Micronutrient levels and nutritional status of school children living in Northwest Ethiopia. Nutr J 2012, 11:108.

doi:10.1186/1756-0500-7-18

Cite this article as: Nepal et al:: Plasma zinc levels, anthropometric and socio-demographic characteristics of school

children in eastern Nepal. BMC Research Notes 2014 7:18

\section{Submit your next manuscript to BioMed Central and take full advantage of:}

- Convenient online submission

- Thorough peer review

- No space constraints or color figure charges

- Immediate publication on acceptance

- Inclusion in PubMed, CAS, Scopus and Google Scholar

- Research which is freely available for redistribution 